This document is confidential and is proprietary to the American Chemical Society and its authors. Do not copy or disclose without written permission. If you have received this item in error, notify the sender and delete all copies.

\title{
pH-Triggered Reversible Multiple Protein-Polymer Conjugation based on Molecular Recognition
}

\begin{tabular}{|r|l|}
\hline Journal: & The Journal of Physical Chemistry \\
\hline Manuscript ID: & jp-2015-066375.R1 \\
\hline Manuscript Type: & Article \\
\hline Date Submitted by the Author: & $07-$ Aug-2015 \\
\hline & $\begin{array}{l}\text { Liu, Juan; University of Basel, Department of Chemistry } \\
\text { Postupalenko, Viktoriia; University of Basel, Department of Chemistry } \\
\text { Palivan, Cornelia; University of Basel, Chemistry Department } \\
\text { Meier, Wolfgang; University of Basel, Department of Chemistry }\end{array}$ \\
\hline
\end{tabular}

\section{SCHOLARONE \\ Manuscripts}




\title{
pH-Triggered Reversible Multiple Protein-Polymer Conjugation based on Molecular Recognition
}

\author{
Juan Liu, Viktoriia Postupalenko, Jason T. Duskey, Cornelia G. Palivan*, Wolfgang Meier* \\ Department of Chemistry, University of Basel, Klingelbergstrasse 80, Basel 4056, Switzerland
}




\begin{abstract}
Polymer conjugation for protein based therapeutics has been developed extensively; but still suffers from conjugation leading to decrease in protein activity, and generates complexes with limited diversity due to general classical systems only incorporating one protein per each complex. Here we introduce a site specific non-covalent protein-polymer conjugation, which can reduce the heterogeneity of the conjugates without disrupting protein function, while allowing for the modulation of binding affinity and stability, affecting the $\mathrm{pH}$ dependent binding of the number of proteins per polymer. We compared classical one protein polymer conjugates with multiple protein polymer conjugates using His-tagged enhanced yellow fluorescence protein $\left(\mathrm{His}_{6}-\mathrm{eYFP}\right)$ and metal-coordinated tris-nitrilotriacetic acid (trisNTA-Me ${ }^{\mathrm{n}+}$ ) in a site-specific way. trisNTA-Me ${ }^{\mathrm{n}+}-\mathrm{His}_{6}$ acts as a reversible linker with $\mathrm{pH}$ triggered release of functional protein from the trisNTA functionalized copolymers. The nature of the selected $\mathrm{Me}^{\mathrm{n}+}$ and number of available trisNTA-Me ${ }^{\mathrm{n}+}$ on poly(N-isopropylacrylamide-co-tris-nitrilotriacetic acid acrylamide) (PNT) copolymers enable predictable modulation of the conjugates binding affinity (0.09-1.35 $\mu \mathrm{M})$, stability, cell toxicity, and $\mathrm{pH}$ responsiveness. This represents a promising platform that allows direct control over the properties of multiple protein polymer conjugates compared to the classical single protein polymer conjugates.
\end{abstract}




\section{INTRODUCTION}

Protein therapeutics is of high importance in almost every field of medicine. ${ }^{1}$ However, there are still a number of challenges in the application of protein therapeutics that have to be overcome. ${ }^{1,2}$ Therapeutic proteins exhibit low stability, fast renal clearance, enzymatic degradation, and are frequently immunogenic. ${ }^{3}$

An elegant way to overcome these problems is to conjugate polymers to proteins, which has been reported to improve protein stability, half-life, solubility, and reduce immunogenicity. ${ }^{4-8}$ However, such conjugation can lead to the alteration of the protein structure, resulting in a decrease or even complete inhibition of protein activity. ${ }^{9,10}$ An effective approach to overcome a loss of protein function is to design stimuli-responsive linkage between polymers and proteins. ${ }^{11}$ This enables the linkage to be independent of the protein function, and therefore, cleavage of the protein from the polymer conjugate by a specific stimulus releases the intact and functional protein. ${ }^{11-13}$ Currently, covalent attachment of polymers to proteins through stimuli-cleavable linkers has mainly been developed. ${ }^{11,13-15}$ Non-covalent interactions with a stimuli-responsive nature are rarely applied for protein-polymer conjugation due to their instability. ${ }^{16,17}$ The interaction between metal-coordinated nitrilotriacetic acid $\left(\mathrm{NTA}-\mathrm{Me}^{\mathrm{n}+}\right)$ and His-tagged proteins is a promising candidate for protein-polymer conjugation, due to the binding specificity and the reversibility upon $\mathrm{pH}$ change or the addition of imidazole or ethylenediaminetetraacetic acid (EDTA). ${ }^{18,19}$ Also, no modification of the protein is required as most recombinant therapeutic proteins expressed by E.coli incorporate his tag $\left(\mathrm{His}_{6}\right)$ for affinity purification, which can also directly coordinate the NTA-Me ${ }^{\mathrm{n}+}$. Unfortunately, to the best of our knowledge, there is only one study published using NTA-Me ${ }^{\mathrm{n}+}-\mathrm{His}_{6}$ for the formation of protein-polymer conjugates for protein therapy, but the conjugates were shown to exhibit low stability due to the poor binding 
affinity. ${ }^{16}$ Supramolecular entities with two or three NTA heads (bisNTA and trisNTA, respectively) exhibit improved binding affinity towards His-tagged proteins, and have been used recently for the formation of protein-polymer conjugates. ${ }^{16,20}$ Among them, trisNTA possesses the highest binding affinity, ${ }^{19,21-24}$ but the stability and the $\mathrm{pH}$-trigged releaseability of trisNTA$\mathrm{Me}^{2+}$-His 6 protein-polymer conjugates is still unknown.

Moreover, most protein-polymer conjugate systems allow for only one protein to be bound to each or multiple polymers. ${ }^{7,25}$ Binding multiple proteins on each polymer would be able to enhance the stability of conjugates due to the inter-protein interactions, similar to many natural stabilized protein assemblies. $^{26-28}$

A previous study published by our group introduced poly(N-isopropylacrylamide-co-trisnitrilotriacetic acid acrylamide) copolymers (PNTn, where $\mathrm{n}$ represents the mol\% of trisNTA on the polymer) containing $\mathrm{Cu}^{2+}$ for specific binding of His-tagged molecules. ${ }^{20}$ Here, we employ PNTn copolymers and His 6 -eYFP (Figure 1) as models for polymer-protein conjugation to analyze the effect on the stability, $\mathrm{pH}$-trigged dissociation, and toxicity when variables such as the nature of the metal, the distance between trisNTA sites, and the addition of inter-protein interactions were varied. Three metal cations, $\mathrm{Cu}^{2+}, \mathrm{Zn}^{2+}$, and $\mathrm{Fe}^{3+}$, were chosen as the coordination center in the trisNTA pocket to modulate the binding affinity of His-tagged proteins to the polymer, and were assessed by isothermal titration calorimetry (ITC). Then their ability to reversibly bind based on changes in $\mathrm{pH}$ was analyzed by fast protein liquid chromatography (FPLC). Also, the protein stability before and after conjugation, as well as after $\mathrm{pH}$ mediated release, were measured by circular dichroism (CD) and fluorescence spectroscopy. Our strategy of multiple protein conjugation to each polymer chain, and release upon $\mathrm{pH}$ changes can be 
expanded to other systems, and advance the application of non-covalent interactions for proteinpolymer conjugation.
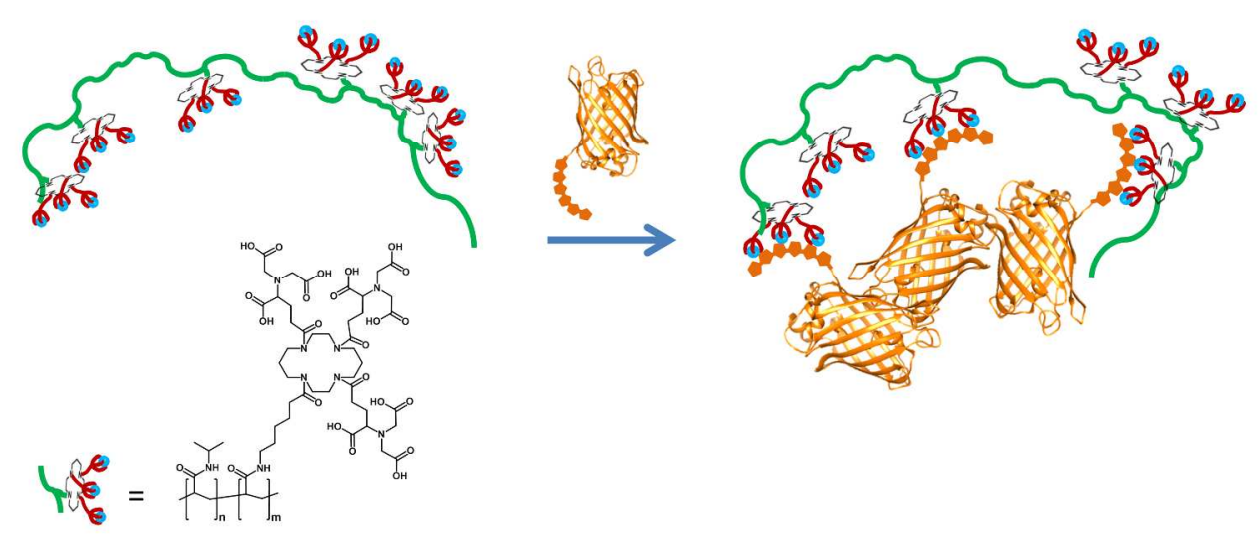

Figure 1. Schematic representation of site-specific conjugation of poly(N-isopropylacrylamideco-tris-nitrilotriacetic acid acrylamide) polymers (green), which coordinate metals (blue) with His-tagged proteins (orange).

\section{EXPERIMENTAL SECTION}

Materials. Copper(II) chloride, zinc chloride, iron(III) sulfate hydrate, Dulbecco's modified eagle medium (DMEM) and phosphate buffered saline (PBS) were purchased from SigmaAldrich and used as received. 3-(4,5-dimethylthiazol-2-yl)-5-(3-carboxymethoxyphenyl)-2-(4sulfophenyl)-2H-tetrazolium (MTS) was purchased from Promega, USA. Penicillin, streptomycin and fetal bovine serum (FBS) were purchased from Life technologies. Rhodamine B labelled hexahistidine (RHB-His ${ }_{6}$ ) was received as a gift from Dr. Thomas Schuster. Pierce ${ }^{\mathrm{TM}}$ BCA Protein Assay was from Thermo Scientific. All chemicals were purchased with the highest purity and used without further purification unless otherwise stated. 
Chelation of metal cations to PNTn copolymers. Respective PNTn $(0.2 \mathrm{mg} / \mathrm{mL})$ were dissolved in PBS, pH 7.4. A stoichiometric excess of $\mathrm{CuCl}_{2}, \mathrm{ZnCl}_{2}$, or $\mathrm{Fe}_{2}\left(\mathrm{SO}_{4}\right)_{3}$ was mixed with the respective PNTn solution and was purified on a HiTrap desalting column (5 mL, GE Healthcare Life Sciences) with PBS as the mobile phase.

Protein expression and analysis. The expression of $\mathrm{His}_{6}$-eYFP was performed as previously published. ${ }^{29}$ The concentration of $\mathrm{His}_{6}$-eYFP was determined by BCA protein assay and measured absorbance at $562 \mathrm{~nm}$.

CD spectra were recorded using AVIV and Applied PhotophysicsChirascan CD spectrophotometers at $25^{\circ} \mathrm{C}$ with a time constant of $5 \mathrm{~s}$ and a step resolution of $1 \mathrm{~nm}$ in a $1 \mathrm{~mm}$ quartz cell. $\mathrm{CD}$ data are given as mean of residual molar ellipticities $\left(\mathrm{deg} \mathrm{cm}^{2} \mathrm{dmol}^{-1}\right)$. The spectra are the result of 2-4 repeats. All measured solutions contained a final concentration of 4 $\mu \mathrm{M} \mathrm{His}_{6}$-eYFP protein in PBS, where the PBS background spectrum was subtracted.

Fluorescence of $100 \mathrm{nM} \mathrm{H_{1 }}{ }_{6}$-eYFP $\left(\lambda_{\text {ex }}=513 \mathrm{~nm}, \lambda_{\mathrm{em}}=524 \mathrm{~nm}\right)$ and polymer-protein conjugates was investigated with a PerkinElmer LS55 fluorescence spectrometer (Waltham, Massachusetts, USA) at ambient temperature. Fluorescence of $60 \mathrm{nM} \mathrm{RHB-His}{ }_{6}$ alone $\left(\lambda_{\mathrm{ex}}=554\right.$ $\mathrm{nm}, \lambda_{\mathrm{em}}=585 \mathrm{~nm}$ ) and in complex with NTA-Cu${ }^{2+}$, trisNTA-Cu ${ }^{2+}$ and PNT4-Cu ${ }^{2+}$ was measured similarly.

Binding ability and affinity of $\mathrm{His}_{6}-\mathrm{eYFP}$ to PNTn-Me ${ }^{2+}$ copolymers. Binding stoichiometry and dissociation constant $\left(K_{\mathrm{D}}\right)$ were determined by ITC. ITC was carried out using a VP-ITC microcalorimeter from MicroCal. Interaction constants characterizing the PNTn-Me ${ }^{2+}$ copolymers and $\mathrm{His}_{6}$-eYFP were determined by direct titration of $\mathrm{His}_{6}$-eYFP into polymer solutions in $\mathrm{PBS} \mathrm{pH} 7.4$ at $25^{\circ} \mathrm{C}$. The concentration of $\mathrm{His}_{6}$-eYFP and trisNTA on PNTn was 70 $\mu \mathrm{M}$ and $6 \mu \mathrm{M}$, respectively. During analysis the solution in the sample cell was stirred at 300 
rpm. The volume of the sample cell and syringe were $1.4 \mathrm{~mL}$ and $295 \mu \mathrm{L}$, respectively. Small aliquots of $\mathrm{His}_{6}$-eYFP (typically $10 \mu \mathrm{L}$ ) were added into the stirring solution over $240 \mathrm{~s}$ to allow complete equilibration. The first injection was set to a volume of $1 \mu \mathrm{L}$ to avoid air in the syringe and ignored for data analysis. Exothermic heat pulse (upper panel, Figure S1) that corresponds to an injection of $10 \mu \mathrm{L}$ of $70 \mu \mathrm{M} \mathrm{His}_{6}$-eYFP to $1.4 \mathrm{~mL}$ of $6 \mu \mathrm{M}$ trisNTA functional group on copolymers was recorded as a function of time. The data were analyzed using the Origin software package supplied by MicroCal and fitted by standard single-site binding model (lower panel, Figure S1). The stoichiometry value is equal to the value of the molar ratio for which the slope of the plot in lower panel is steepest. The slope of the plot at this point gives the value of the reciprocal of the dissociation constant.

Stability and pH-trigged dissociation of PNTn-Me ${ }^{2+}-\mathrm{His}_{6}-\mathrm{eYFP}$ conjugates. FPLC was used for the analysis of the stability and the $\mathrm{pH}$ responsiveness of PNTn-Me ${ }^{2+}-\mathrm{His}_{6}$-eYFP conjugates. $250 \mu \mathrm{M} \mathrm{His}{ }_{6}$-eYFP was incubated with a metal cation-coordinated PNTn in PBS with a molar ratio of $1: 2$ for His $_{6}$-eYFP : trisNTA. The solution $(500 \mu \mathrm{L})$ was loaded onto a Superdex 200 10/300 GL (Akta Prime system, Amersham Biosciences, measuring @ 513 nm), and eluted with a PBS mobile phase. For the investigation of $\mathrm{pH}$ responsiveness, the column was equilibrated with PBS solution at $\mathrm{pH} 5.0$ or 6.0. The sample was prepared in the same way as previously described, loaded onto the column and eluted with PBS solution at $\mathrm{pH} 5.0$ or 6.0. The data were analyzed by Fityk software to calculate the integral area of the individual peaks.

Structure of PNTn-Me ${ }^{2+}-H_{1} s_{6}-$ eYFP conjugates. The size of PNTn-Me ${ }^{2+}-\mathrm{His}_{6}-\mathrm{eYFP}$ conjugates were investigated by dynamic light scattering (DLS) with a Zetasizer Nano ZSP (Malvern Instruments Ltd., UK) at $25^{\circ} \mathrm{C}$ in PBS. The data were fit based on number distribution. The concentration of His $_{6}$-eYFP was $20 \mu \mathrm{M}$ and $800 \mu \mathrm{L}$ of solution was used for measurements. 
The negatively stained image of PNT4-Zn ${ }^{2+}-\mathrm{His}_{6}$-eYFP conjugates $(0.1 \mathrm{mg} / \mathrm{mL}, 5 \mu \mathrm{L})$ stained with $2 \%$ uranyl acetate was performed on a transmission electron microscope (Philips CM100) at an acceleration voltage of $80 \mathrm{kV}$. The size of the conjugates was analyzed using ImageJ software.

Cell culture. Hela cells or U87 glioblastoma cells were maintained at $37{ }^{\circ} \mathrm{C}$ in a $5 \% \mathrm{CO}_{2}$ humidified atmosphere and were grown in DMEM with 10\% FBS, 100 units/mL penicillin, 100 $\mu \mathrm{g} / \mathrm{mL}$ streptomycin and $2 \mathrm{mM}$ L-glutamine.

Cell viability. Cytotoxicity testing was performed using the PromegaCellTiter 96 AQueous NonRadioactive Cell Proliferation (MTS) assay (Promega, USA) to determine the number of viable cells in culture. Hela and U87 cells were seeded in a 96-well plate the night before experiments at $0.5 \times 104$ and $1 \times 104$ cells/well in $100 \mu 1$, respectively. The day of the experiment, samples $(10 \mu \mathrm{L})$ containing different amount of PNT4-Me ${ }^{2+}(0-375 \mu \mathrm{g} / \mathrm{mL})$, were added to the cells. Twenty-four hours later, $20 \mu \mathrm{L}$ of MTS solution were added to each well and incubated for $3 \mathrm{~h}$ at $37^{\circ} \mathrm{C}$. Cell viability was calculated by measuring the absorbance at $490 \mathrm{~nm}$ using a 96-well plate reader and plotted relative to untreated cells that were grown the same day in the same plate and assays were performed in triplicate.

\section{RESULTS AND DISCUSSION}

Binding stoichiometry of His - $^{-e Y F P}$ to PNTn coordinated with different metal cations. PNT copolymers were previously synthesized and the average distance between trisNTA binding sites of PNT1, PNT2, PNT4, and PNT7 of $31.5 \mathrm{~nm}, 13.2 \mathrm{~nm}, 5.2 \mathrm{~nm}$ and $4.3 \mathrm{~nm}$, were theoretically calculated, assuming an idealized linear polymer chain, by dividing the length of the polymer chain by the corresponding metal content. These calculations resulted in an average number of 2 , 
4, 7 and 9 trisNTA per polymer, respectively (Table S1). ${ }^{20}$ Here we are interested to modulate the binding affinity of His-tagged proteins to these polymer chains decorated with tris-NTA groups, and in this respect, we selected three different metal cations, $\mathrm{Cu}^{2+}, \mathrm{Zn}^{2+}$, or $\mathrm{Fe}^{3+}$. The binding stoichiometry of $\mathrm{His}_{6}$-eYFP to the PNT-Me ${ }^{\mathrm{n}+}$ was assessed by ITC in order to calculate the dependence of the metal and of the distance between trisNTA sites on binding stoichiometry (Figure 2, S1). His $_{6}$-eYFP coordinated the $\mathrm{Cu}^{2+}$ or $\mathrm{Zn}^{2+}$ metals on PNTn copolymers with a maximum binding stoichiometry approaching $0.9: 1$ or $0.85: 1$, respectively, when the average distance between trisNTA binding sites was larger than the size of His $_{6}$-eYFP and steric hindrance did not block efficient binding. However, even though PNT7 has a higher content of trisNTA-Me ${ }^{2+}$ sites, a lower binding stoichiometry was observed (0.55 and 0.53 His $_{6}$-eYFP to trisNTA- $\mathrm{Cu}^{2+}$ and trisNTA- $\mathrm{Zn}^{2+}$ sites) due to steric hindrance, resulting from the coil conformation of the polymer in solution. In the case of PNTn containing trisNTA-Fe ${ }^{3+}$, no coordination of His $_{6}$-eYFP was observed by ITC even when a high concentration of His $_{6}$-eYFP $(180 \mu \mathrm{M})$ was added (data not shown).

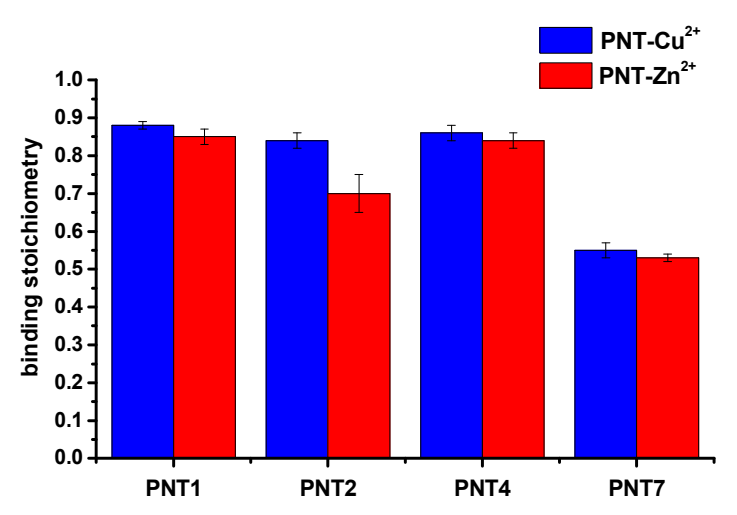

Figure 2. Binding stoichiometry between trisNTA-Me ${ }^{2+}$ in PNTn and $\mathrm{His}_{6}-\mathrm{eYFP}$. 
Binding affinity of His $_{6}$-eYFP to PNTn-Me ${ }^{2+}$ copolymers. In addition to calculating the binding stoichiometry, the binding affinity of $\mathrm{His}_{6}$-eYFP to PNTn containing either $\mathrm{Cu}^{2+}$ or $\mathrm{Zn}^{2+}$ was compared where the $K_{\mathrm{D}}$ value was normalized per NTA functional group per polymer chain to allow for comparison between the polymers containing different average number of binding sites. Similar to PNTn-Cu ${ }^{2+}(0.09-0.39 \mu \mathrm{M}), K_{\mathrm{D}}$ values for PNTn-Zn ${ }^{2+}-\mathrm{His}_{6}$-eYFP depended on the average distance between trisNTA binding sites. When the distance was decreased from 31.5 $\mathrm{nm}$ to $4.3 \mathrm{~nm}\left(\mathrm{PNT} 1-\mathrm{Zn}^{2+}{ }^{2-} \mathrm{His}_{6}-\mathrm{eYFP}\right.$ and PNT7-Zn ${ }^{2+}-\mathrm{His}_{6}-\mathrm{eYFP}$, respectively), the $K_{\mathrm{D}}$ values decreased from $1.35 \pm 0.12 \mu \mathrm{M}$ to $0.46 \pm 0.06 \mu \mathrm{M}$. It is known that numerous factors play a role in the binding strength of a metal to its coordination pocket including size, charge, protein oligomerization and other stabilizing or destabilizing interactions. ${ }^{30-33}$ For example, increasing the number of binding sites could decrease the $K_{D}$ of a small molecule due to a decreased rate of dissociation. On the contrary if the size of proteins is larger than the mean distance between trisNTA-Me ${ }^{\mathrm{n}+}$ sites, the binding affinity is decreased even if an increased number of coordination is present due to steric hindrance and charge repulsion of the protein. ${ }^{20}$ However, increasing the number of trisNTA-Me ${ }^{2+}$ per polymer, effectively decreasing their separation, stabilized the conjugate. While many factors play a role in affinity, this decrease of $\mathrm{K}_{\mathrm{D}}$ supports the previous findings that a decrease of enthalpy was seen upon binding of PNT4 compared to PNT1 copolymers indicating an increase in hydrogen bond formation from inter-protein interactions. ${ }^{30-}$ ${ }^{33}$ This led to a binding affinity dependency of PNTn-Me ${ }^{2+}-\mathrm{His}_{6}$-eYFP based on a combined effect between the coordination strength of the metal and the amount of inter-protein interactions, which overcomes the coil-hindrance (Figure 3). 


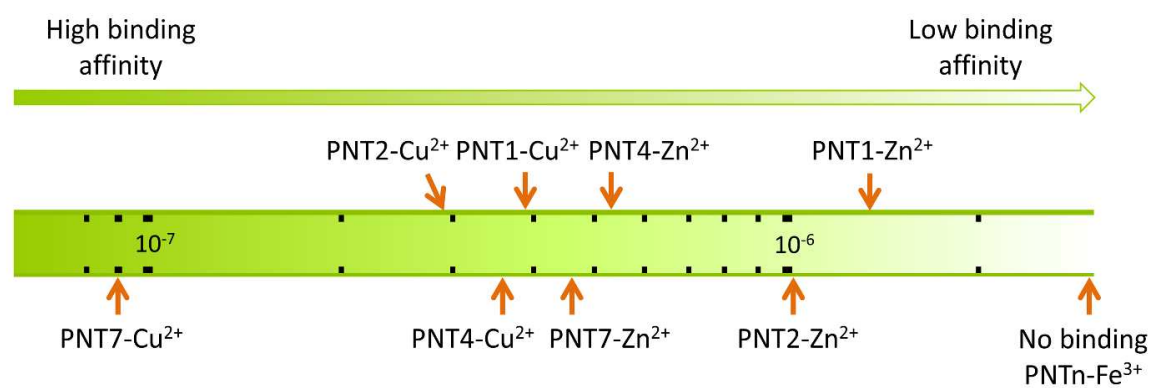

Figure 3. $K_{\mathrm{D}}(\mathrm{M})$ for the binding between PNTn- $\mathrm{Cu}^{2+} / \mathrm{Zn}^{2+} / \mathrm{Fe}^{3+}$ and $\mathrm{His}_{6}-\mathrm{eYFP}$ at $\mathrm{pH}=7.4$.

The binding affinity of His-tagged proteins is dependent on the strength of coordination with the metal where $\mathrm{Cu}^{2+}>\mathrm{Ni}^{2+}>\mathrm{Zn}^{2+}>\mathrm{Fe}^{3+} \cdot 34$ Therefore, $\mathrm{Zn}^{2+}$ is rarely used for NTA conventional applications, such as purification of proteins, due to its poor binding affinity $\left(\log _{10} K=3.25 \mathrm{M}^{-}\right.$ $\left.{ }^{1}\right) .{ }^{35}$ Even with the increased binding created by using trisNTA instead of NTA or bisNTA, it is apparent that when inter-protein interactions are not present, as is the case for PNT1, the binding affinity with $\mathrm{Zn}^{2+}$ is still much weaker than its $\mathrm{Cu}^{2+}$ equivalent. By increasing the inter-protein interactions as a result of an increased number of accessible trisNTA coordination pockets, the binding affinity increases due to stabilization of the conjugates. However, for PNT7 the steric hindrance leads to a decrease in binding stoichiometry as described above. Introducing interprotein interactions leads to more stable $\mathrm{Zn}^{2+}$ conjugates, which makes them suitable for further applications (Figure 3). This strategy is seen in nature to stabilize self-assembled structures by inter-protein interactions. $^{26-28}$

Physical characteristics of PNTn-Me ${ }^{2+}-\mathrm{His}_{6}-\mathrm{eYFP}$ conjugates and protein stability. The size of PNTn-Me ${ }^{2+}-\mathrm{His}_{6}$-eYFP conjugates was characterized by DLS. PNT1-Cu ${ }^{2+} / \mathrm{Zn}^{2+}$ and PNT4$\mathrm{Cu}^{2+} / \mathrm{Zn}^{2+}$ were chosen as representative polymers for further investigations including size measurements and stabilities in various pHs. Even though PNT1 has an average number of 2 trisNTA-Me ${ }^{2+}$ binding sites per polymer, in order to compare a multiple protein system to the 
classical one protein per PNT1, a $2: 1$ ratio of trisNTA-Me ${ }^{2+}$ to His $_{6}$-eYFP was chosen. Also, since the binding studies showed a stoichiometry $<1$ for PNTn polymers to the average number of binding sites, this means each polymer solution has a mixture of polymers containing an average number of accessible binding sites less than the theoretical value ( 2 for PNT1, and 7 for PNT4). Therefore, this $2: 1$ ratio was used for both PNTn to keep the number of proteins proportional on each polymer chain. For this molar ratio, there are an average of 3 or $4 \mathrm{His}_{6}{ }^{-}$ eYFPs per polymer chain for PNT4, and an average of one His $_{6}$-eYFP per polymer chain for

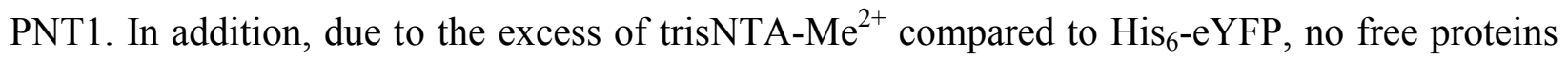
are expected.

In order to directly measure the size shift of the tertiary structure of polymer chains in solution due to the binding of proteins, dynamic light scattering was performed. The hydrodynamic diameter $\left(D_{\mathrm{H}}\right)$ of $\mathrm{His}_{6}$-eYFP was determined to be $5.0 \pm 0.9 \mathrm{~nm}$. The $D_{\mathrm{H}}$ of PNT1-Zn ${ }^{2+}$ was $8.1 \pm$ $2.5 \mathrm{~nm}$ and when coordinated with $\mathrm{His}_{6}$-YFP increased in size to $9.7 \pm 2.4 \mathrm{~nm}$ (Figure S3). PNT4-Zn ${ }^{2+}$ was $5.8 \pm 1.8 \mathrm{~nm}$ (Figure S2) and after binding, the diameter value shifted to $13.1 \pm$ $2.8 \mathrm{~nm}$, which was similar to PNT4- $\mathrm{Cu}^{2+}-\mathrm{His}_{6}$-eYFP (data not shown). The change in size between PNT1-Zn ${ }^{2+}$ and PNT4-Zn ${ }^{2+}$ after binding His $6_{6}$-YFP can be explained by the increased average number of proteins per polymer. The DLS data was supported with transmission electron microscopy (TEM), revealing structures with a diameter of $12 \pm 3 \mathrm{~nm}$ for PNT4-Zn ${ }^{2+}-\mathrm{His}_{6}$-eYFP (Figure S4).

To address the question of whether the conjugation of polymers to proteins causes alterations in their secondary structure, His $6_{6}$-YFP was characterized before and after polymer conjugation by CD spectroscopy. The far-UV CD spectra of $\mathrm{His}_{6}$-eYFP and PNT1/4-Zn ${ }^{2+}-\mathrm{His}_{6}$-eYFP, showed 
that conjugation did not alter the protein structure (Figure S5), agreeing with the previously published results. $^{20,36}$

PNTn-Me ${ }^{2+}$-His 6 -eYFP stability under varying pHs. The stability of PNTn-Me ${ }^{2+}-\mathrm{His}_{6}-\mathrm{eYFP}$ conjugates under various pH's was investigated by FPLC. Each of the protein-polymer conjugates were measured to establish a baseline of the amount of free $\mathrm{His}_{6}$-eYFP in each and calculated as a percent of intact protein-polymer complex (Figure 4,). PNT1-Cu ${ }^{2+}-\mathrm{His}_{6}-\mathrm{eYFP}$ showed a lower stability than PNT4-Cu ${ }^{2+}-\mathrm{His}_{6}-\mathrm{eYFP}$ at $\mathrm{pH} 7.4$ (Figure S6). The difference between PNT1-Zn ${ }^{2+}-\mathrm{His}_{6}-\mathrm{eYFP}$ and PNT4-Zn ${ }^{2+}-\mathrm{His}_{6}-\mathrm{eYFP}$ was even more significant with only $46.6 \%$ of $\mathrm{His}_{6}$-eYFP remaining bound with PNT1-Zn ${ }^{2+}$ while $80.2 \%$ of His $_{6}$-eYFP remaining complexed with PNT4-Zn ${ }^{2+}$. Because PNTn-Me ${ }^{2+}$ copolymers are highly negatively-charged, ${ }^{20}$ the potential electrostatic interactions between protein-polymer conjugates and gel filtration media might decrease the stability of conjugates during the FPLC analysis. ${ }^{37-39}$ This was tested by increasing the number of available PNT4- $\mathrm{Zn}^{2+}$ from 2 to 10 equivalents compared to His $6^{-}$ eYFP. Even with a 5 fold increase in potential interaction sites, the $\%$ of free protein remained the same suggesting that the phenomena was caused by interaction with the column (Figure S7). The higher stability of PNT4-Me ${ }^{2+}-\mathrm{His}_{6}-\mathrm{eYFP}$ compared to PNT1-Me ${ }^{2+}-\mathrm{His}_{6}-\mathrm{eYFP}$ is attributed to inter-protein interactions preventing the disassociation of the complex, in agreement with the binding affinity values. Inter-protein interactions stabilize the protein-polymer conjugates when the number of trisNTA groups is increased (PNT4 compared with PNT1) strengthening the interaction when the metal is not a strong coordination center $\left(\mathrm{Zn}^{2+}\right)$. 

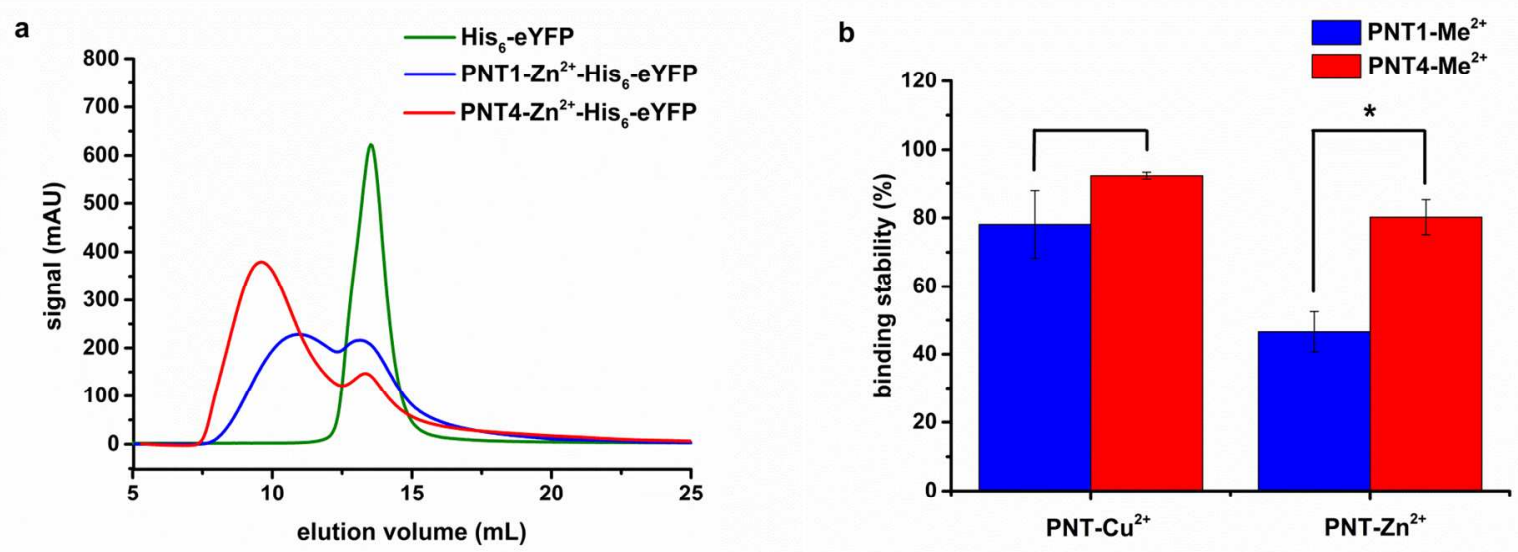

Figure 4. Stability of PNTn-Me ${ }^{2+}-\mathrm{His}_{6}-\mathrm{eYFP}$ conjugates at $\mathrm{pH}$ 7.4. (a) FPLC chromatograms of His $_{6}$-eYFP and PNT1/4-Zn ${ }^{2+}$-His $_{6}$-eYFP. (b) The percentage of His ${ }_{6}$-eYFP bound with PNT1/4$\mathrm{Me}^{2+}$. Stars indicate significance in two-tailed Student's t-test; $* \mathrm{P}<0.05, \mathrm{n}=3$.

An attractive property of $\mathrm{NTA}-\mathrm{Me}^{2+}-\mathrm{His}_{6}$ molecular recognition is $\mathrm{pH}$ sensitive binding. ${ }^{18}$ However, this property has previously not been proven with trisNTA protein-polymer conjugates. In order to investigate the $\mathrm{pH}$ sensitive binding, a model peptide, hexahistidine labeled with Rhodamine B (RHB-His ${ }_{6}$ ) was used to compare the parameters that effect binding stability across various pHs. RHB-His 6 is strongly quenched when bound to $\mathrm{Cu}^{2+}$, and more stable than eYFP at lower $\mathrm{pH}^{40}$ The binding of trisNTA- $\mathrm{Cu}^{2+}$ to $\mathrm{RHB}^{4} \mathrm{His}_{6}$ resulted in a significant decrease of fluorescent intensity from 570 to 60 . The fluorescent intensity remained unchanged at all $\mathrm{pH}>3.5$ (Figure $\mathrm{S} 8$ ), indicating that the binding between trisNTA- $\mathrm{Cu}^{2+}$ and RHB-His $_{6}$ is stable at various pHs. PNT4-Cu ${ }^{2+}-\mathrm{RHB}^{-\mathrm{His}_{6}}$ exhibited no dissociation with $\mathrm{pH}>$ 3.5, suggesting that the presence of polymer does not significantly influence the binding stability. Also, PNT4- $\mathrm{Cu}^{2+}$ did not show a significant release of $\mathrm{His}_{6}$-eYFP when the $\mathrm{pH}$ was changed from 7.4 to 6.0 , but $52 \%$ of the conjugates disassociated at $\mathrm{pH} 5.0$, respectively (Figure 5). As expected, due to the lack of inter-protein interactions, the release of $\mathrm{His}_{6}$-eYFP was more 
pronounced for $\mathrm{PNT} 1-\mathrm{Cu}^{2+}$ at $\mathrm{pH}$ values down to 6 , ending at $\mathrm{pH}=5$ to a similar fraction of dissociated conjugates (53\%). The higher percent of $\mathrm{pH}$-trigged dissociation can be attributed the higher $K_{\mathrm{D}}$ at $\mathrm{pH} 7.4$ of PNT4-Cu ${ }^{2+}$-His ${ }_{6}$-YFP $\left(K_{\mathrm{D}}=0.36 \mu \mathrm{M}\right)$ compared with PNT4-Cu ${ }^{2+}$-RHBHis $_{6}\left(K_{\mathrm{D}}=0.13 \mu \mathrm{M}\right) .{ }^{20}$ In contrast with PNTn-Cu${ }^{2+}$, both PNT1-Zn ${ }^{2+}$ and PNT4-Zn ${ }^{2+}$ exhibited a more rapid dissociation. At $\mathrm{pH}$ 7.4 $\mathrm{PNT} 1-\mathrm{Zn}^{2+}$ and $\mathrm{PNT} 4-\mathrm{Zn}^{2+}$ dissociated from $\mathrm{His}_{6}$-eYFP at $53.4 \%$ compared to $19.8 \%$ determined by FPLC, respectively. Decreasing the $\mathrm{pH}$ to 6.0 increased the dissociation of His $_{6}$-eYFP from PNT1- $\mathrm{Zn}^{2+}$ and PNT4- $\mathrm{Zn}^{2+}$ to $92 \%$ and $76 \%$, respectively, with both conjugates being completely unbound by $\mathrm{pH} 5.0$ (Figure $5 \mathrm{a}, \mathrm{b}$ ). The higher dissociation of PNTn- $\mathrm{Zn}^{2+}-\mathrm{His}_{6}-\mathrm{eYFP}$ compared with PNTn-Cu ${ }^{2+}-\mathrm{His}_{6}-\mathrm{eYFP}$ at lower $\mathrm{pH}$ was expected, due to the higher $K_{D}$ values $(0.46-1.35 \mu \mathrm{M}, 0.09-0.39 \mu \mathrm{M}$, respectively). The trisNTA- $\mathrm{Cu}^{2+}$ binding sites on PNTn have stronger interaction with $\mathrm{His}_{6}$-eYFP compared with protons $\left(K_{\mathrm{D}} \approx 1 \mu \mathrm{M}\right),{ }^{18,41}$ therefore it is difficult to be protonated to induce the dissociation of the proteins. However, the affinity of trisNTA- $\mathrm{Zn}^{2+}$ on PNTn to His $6_{6}-\mathrm{eYFP}$ is comparable to that of protons, resulting in direct competition between protonation and coordination of the $\mathrm{His}_{6}$-eYFP. This led to PNTn- $\mathrm{Zn}^{2+}{ }^{2} \mathrm{His}_{6}$-eYFP having a higher amount of $\mathrm{pH}$-trigged release than PNT-Cu${ }^{2+}$ His $_{6}$-eYFP. Furthermore, the reversibility of $\mathrm{pH}$ dependent binding of PNT4-Zn ${ }^{2+}-\mathrm{His}_{6}$-eYFPwas investigated due to its higher $\mathrm{pH}$ binding dependence. A solution of PNT4- $\mathrm{Zn}^{2+}-\mathrm{His}_{6}$-eYFP was formed in $\mathrm{pH} 7.4$ and tested for stability, the $\mathrm{pH}$ was then decreased to 5.0 and dissociation was observed. However, when the $\mathrm{pH}$ was increased back to $\mathrm{pH} 7.4$ almost complete reformation of all protein complexes was observed (Figure 5c). 


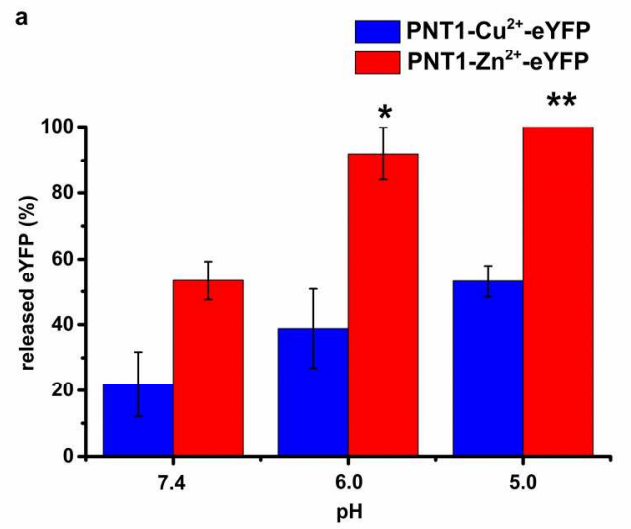

c

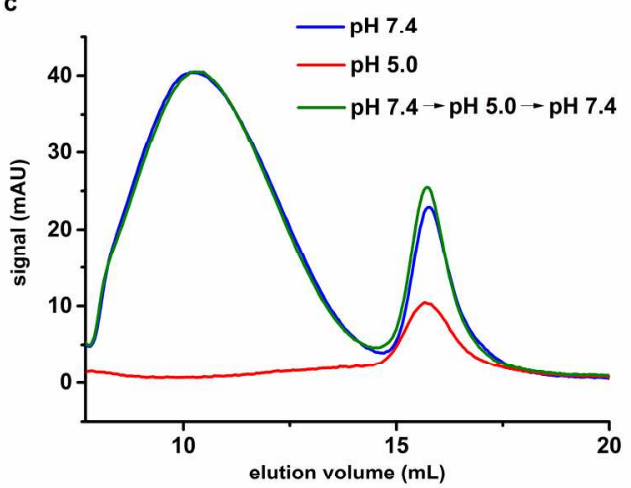

b
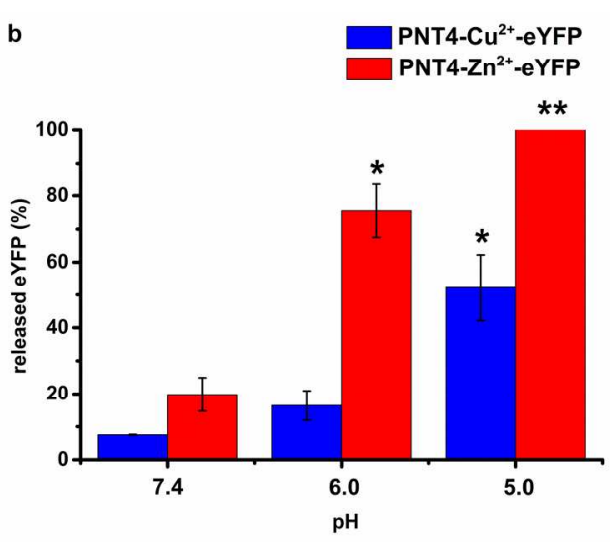

d

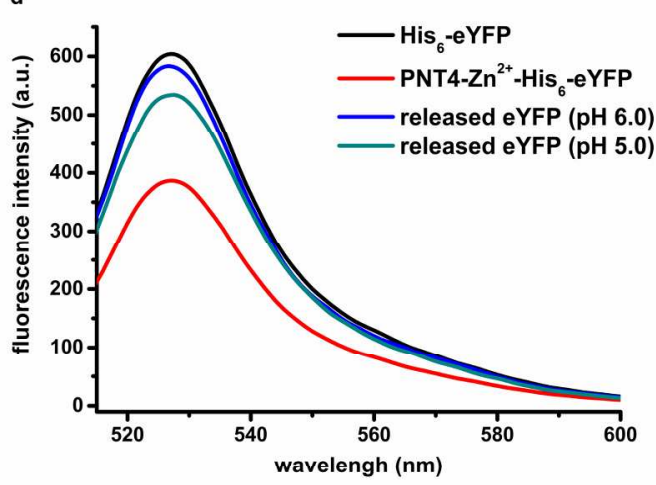

Figure 5. Release of $\mathrm{His}_{6}-\mathrm{eYFP}$ from PNT1-Me ${ }^{2+}$ (a) and PNT4-Me ${ }^{2+}$ (b) at different pH values. All statistics were analyzed by comparing samples to their respective protein-polymer conjugate at $\mathrm{pH}$ 7.4. Stars indicate significance compared to the equivalent protein polymer conjugate at pH 7.4 in a two-tailed Student's t-test; ${ }^{*} \mathrm{P}<0.05$, $* * \mathrm{P}<0.005$. (c) Reversibility of $\mathrm{pH}$ dependent binding between PNT4- $\mathrm{Zn}^{2+}$ and His ${ }_{6}$-eYFP analyzed by FPLC. (d) The fluorescence emission spectra of His $_{6}$-eYFP and PNT4-Zn ${ }^{2+}$-His 6 -eYFP before and after release in acidic conditions. While reactions were run in acidic conditions, all samples were analyzed at pH 7.4 in PBS.

To address the question of whether the reversible binding of PNTn copolymers to His ${ }_{6}$-eYFP influence its fluorescent property, His $_{6}$-eYFP was characterized by fluorescence spectroscopy before and after polymer conjugation (Figure 5d). When His $_{6}$-eYFP was conjugated with PNT4- 
$\mathrm{Zn}^{2+}$, a decrease in fluorescence intensity was observed due to the chelation with $\mathrm{Zn}^{2+}$. After dissociation from PNT4- $\mathrm{Zn}^{2+}$ in acidic conditions $(\mathrm{pH}=5.0$ or 6.0$)$, the released His $_{6}$-eYFP was collected and then buffered back to $\mathrm{pH} 7.4$, the fluorescence of $\mathrm{His}_{6}$-eYFP recovered almost to its original value. The slight decrease of fluorescence intensity was due to short-term exposure to acidic condition which corresponds to literature precedence. ${ }^{42}$ In addition, the second structure of dissociated His $_{6}$-eYFP after buffering back pH 7.4 was evaluated by CD spectroscopy. No obvious change of the spectrum was observed, suggesting His $_{6}$-eYFP was kept intact during the pH-triggered dissociation (Figure S9). Therefore, PNTn copolymers are able to bind His ${ }_{6}$-eYFP at physiological $\mathrm{pH}$ and release the bound protein in acidic conditions without influencing the structure and properties.

Cytotoxicity evaluation of PNT4-Me ${ }^{\mathrm{n}+}$ copolymers. The cytotoxicity of PNT4-Me ${ }^{\mathrm{n}+}$ copolymers was evaluated on U87 and HeLa cells by using the MTS assay (Figure 6). PNT4 copolymer showed low toxicity in all range of concentrations tested in both cell lines. The coordination of PNT4 with $\mathrm{Zn}^{2+}$ did not induce toxicity in contrast to PNT4 coordinated with $\mathrm{Cu}^{2+}$ or $\mathrm{Ni}^{2+}$ that showed toxicity with increasing concentrations (Figure $\mathrm{S} 10$ ). trisNTA coordinated with $\mathrm{Cu}^{2+}, \mathrm{Ni}^{2+}, \mathrm{Zn}^{2+}$ was tested as a control and showed slightly higher toxicity compared to equivalent copolymer samples (Figure $\mathrm{S} 10$ ). Repeat administrations of $\mathrm{Cu}^{2+}$ or $^{2+}$ can accumulate in the liver, kidney, and spleen, leading to organ damage after the complex has dissociated and the metal released. ${ }^{43-46}$ Therefore in terms of its low toxicity, a protein-polymer conjugate comprised of PNT4 and $\mathrm{Zn}^{2+}$ would be suitable for further in vitro studies. 

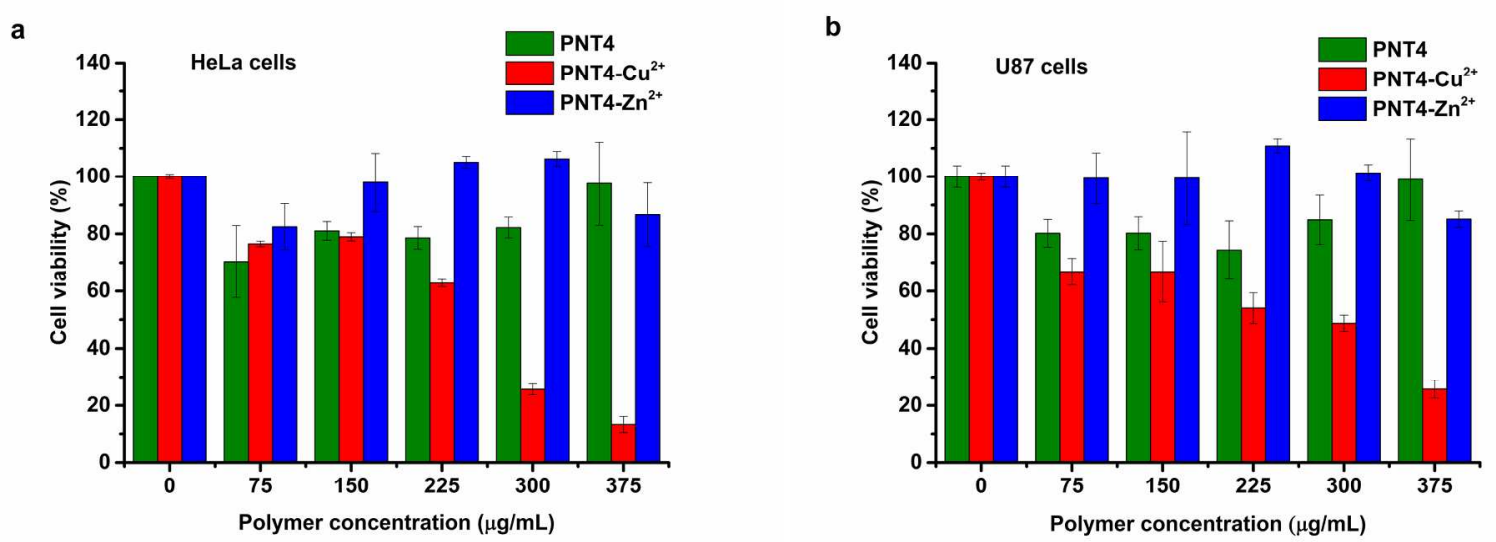

Figure 6. Toxicity evaluation of PNT4-Me ${ }^{\mathrm{n}+}$ copolymers on HeLa (a) and U87 (b) cells using MTS assay where zero polymer concentration refers to the addition of PBS to the cells. Errors bars represent the standard deviation $(n=3)$.

\section{CONCLUSION}

An efficient method to site-specifically and reversibly bind multiple proteins per polymer chain using trisNTA-Me ${ }^{2+}-\mathrm{His}_{6}$ molecular recognition was designed. His ${ }_{6}$-eYFP was used as a model protein for binding PNT-Me ${ }^{\mathrm{n}+}$ copolymers. It was demonstrated that the nature of the $\mathrm{Me}^{\mathrm{n}+}$ and the number of metal binding pockets of trisNTA enable great selectivity for the binding affinity. This led to control of the stability and $\mathrm{pH}$ triggered release of the protein from the polymer by modulating inter-protein interactions. After complete release of $\mathrm{His}_{6}$-eYFP from PNT-Me ${ }^{2+}$ copolymers at selective $\mathrm{pH}$, the return of fluorescence suggested that the protein was intact and maintained its properties. In addition, the toxicity problem of trisNTA-Me ${ }^{\mathrm{n}+}$ and its derivatives, has been improved by using $\mathrm{Zn}^{2+}$, which still maintained the binding with $\mathrm{His}_{6}$-eYFP due to controllable inter-protein interactions.

The presented system advances the field from covalent single protein-polymer conjugates to noncovalent multiple protein-polymer conjugates that can be readily formed and dissociated 
dependent on $\mathrm{pH}$, and serves as a platform for the combination of various active agents into one nanosystem to potentially fulfill multiple tasks such as therapy and diagnosis in a combined manner.

\section{ASSOCIATED CONTENT}

\section{Supporting information}

Characterization of protein-polymer conjugates, additional cell toxicity data, fluorescent spectra of trisNTA-Cu ${ }^{2+}-\mathrm{RHB}^{-} \mathrm{His}_{6}$ in various $\mathrm{pH}$ and $\mathrm{CD}$ spectra of $\mathrm{His}_{6}-\mathrm{eYFP}$. This material is available free of charge via the Internet at http://pubs.acs.org.

\section{AUTHOR INFORMATION}

\section{Corresponding Authors \\ * tel: +41 (0)61 26738 39; fax: +41 (0)61 26738 55; cornelia.palivan@unibas.ch \\ * tel: +41 (0)61 26738 02; fax: +41 (0)61 26738 55; wolfgang.meier@unibas.ch}

\section{Notes}

The authors declare no competing financial interest.

\section{ACKNOWLEDGMENT}

We thank Swiss National Science Foundation and University of Basel for financial support. J. L. thanks China Scholarship Council for supporting the fee to study abroad. We thank Biozentrum Biophysics Facility Basel for the use of their ITC instrument. J. L. thanks Mariana Spulber from University of Basel for extensive discussions.

\section{REFERENCES}


(1) Leader, B.; Baca, Q. J.; Golan, D. E. Protein Therapeutics: a Summary and Pharmacological Classification. Nat. Rev. Drug Discov. 2008, 7, 21-39.

(2) Frokjaer, S.; Otzen, D. E. Protein Drug Stability: a Formulation Challenge. Nat. Rev. Drug Discov. 2005, 4, 298-306.

(3) De Groot, A. S.; Scott, D. W. Immunogenicity of Protein Therapeutics. Trends Immunol. 2007, 28, 482-490.

(4) Duncan, R. Polymer Conjugates as Anticancer Nanomedicines. Nat. Rev. Cancer. 2006, $6,688-701$.

(5) Knop, K.; Hoogenboom, R.; Fischer, D.; Schubert, U. S. Poly(ethylene glycol) in Drug Delivery: Pros and Cons as Well as Potential Alternatives. Angew. Chem., Int. Ed. 2010, 49, 6288-6308.

(6) Kolate, A.; Baradia, D.; Patil, S.; Vhora, I.; Kore, G.; Misra, A. PEG - aVersatile Conjugating Ligand for Drugs and Drug Delivery Systems. J. Control. Release 2014, 192, 67-81.

(7) Pelegri-O’Day, E. M.; Lin, E.-W.; Maynard, H. D. Therapeutic Protein-Polymer Conjugates: Advancing Beyond PEGylation. J. Am. Chem. Soc. 2014, 136, 14323-14332.

(8) Harris, J. M.; Chess, R. B. Effect of Pegylation on Pharmaceuticals. Nat. Rev. Drug Discov. 2003, 2, 214-221.

(9) Gauthier, M. A.; Klok, H.-A. Polymer-Protein Conjugates: an Enzymatic Activity Perspective. Polym. Chem. 2010, 1, 1352-1373. 
(10) Secundo, F. Conformational Changes of Enzymes upon Immobilisation. Chem. Soc. Rev. 2013, 42, 6250-6261.

(11) Filpula, D.; Zhao, H. Releasable PEGylation of Proteins with Customized Linkers. Adv. Drug Deliv. Rev. 2008, 60, 29-49.

(12) Tao, L.; Liu, J.; Xu, J.; Davis, T. P. Bio-Reversible polyPEGylation. Chem. Commun. 2009, 6560-6562.

(13) Gong, Y.; Leroux, J.-C.; Gauthier, M. A. Releasable Conjugation of Polymers to Proteins. Bioconjugate Chem. 2015, DOI: 10.1021/bc500611k.

(14) Kulkarni, S.; Schilli, C.; Grin, B.; Müller, A. H. E.; Hoffman, A. S.; Stayton, P. S. Controlling the Aggregation of Conjugates of Streptavidin with Smart Block Copolymers Prepared via the RAFT Copolymerization Technique. Biomacromolecules 2006, 7, 2736-2741.

(15) Chen, J.; Zhao, M.; Feng, F.; Sizovs, A.; Wang, J. Tunable Thioesters as "Reduction" Responsive Functionality for Traceless Reversible Protein PEGylation. J. Am. Chem. Soc. 2013, $135,10938-10941$.

(16) Kim, T. H.; Swierczewska, M.; Oh, Y.; Kim, A.; Jo, D. G.; Park, J. H.; Byun, Y.; Sadegh-Nasseri, S.; Pomper, M. G.; Lee, K. C. et al. Mix to Validate: a Facile, Reversible PEGylation for Fast Screening of Potential Therapeutic Proteins In Vivo. Angew. Chem., Int. Ed. 2013, 52, 6880-6884.

(17) Nguyen, T. H.; Kim, S.-H.; Decker, C. G.; Wong, D. Y.; Loo, J. A.; Maynard, H. D. A Heparin-Mimicking Polymer Conjugate Stabilizes Basic Fibroblast Growth Factor. Nat Chem. 2013, 5, 221-227. 
(18) June, R. K.; Gogoi, K.; Eguchi, A.; Cui, X.-S.; Dowdy, S. F. Synthesis of a pH-Sensitive Nitrilotriacetic Linker to Peptide Transduction Domains to Enable Intracellular Delivery of Histidine Imidazole Ring-Containing Macromolecules. J. Am. Chem. Soc. 2010, 132, 1068010682.

(19) André, T.; Reichel, A.; Wiesmüller, K.-H.; Tampé, R.; Piehler, J.; Brock, R. Selectivity of Competitive Multivalent Interactions at Interfaces. ChemBioChem 2009, 10, 1878-1887.

(20) Liu, J.; Spulber, M.; Wu, D.; Talom, R. M.; Palivan, C. G.; Meier, W. Poly(NIsopropylacrylamide-co-Tris-Nitrilotriacetic Acid Acrylamide) for a Combined Study of Molecular Recognition and Spatial Constraints in Protein Binding and Interactions. J. Am. Chem. Soc. 2014, 136, 12607-12614.

(21) Lata, S.; Reichel, A.; Brock, R.; Tampé, R.; Piehler, J. High-Affinity Adaptors for Switchable Recognition of Histidine-Tagged Proteins. J. Am. Chem. Soc. 2005, 127, 1020510215.

(22) Grunwald, C.; Schulze, K.; Reichel, A.; Weiss, V.; Blaas, D.; Piehler, J.; Wiesmüller, K.; Tampé, R. In Situ Assembly of Macromolecular Complexes Triggered by Light. Proc. Natl. Acad. Sci. U.S.A. 2010, 107, 6146.

(23) Huang, Z.; Hwang, P.; Watson, D. S.; Cao, L.; Szoka, F. C. Tris-Nitrilotriacetic Acids of Subnanomolar Affinity Toward Hexahistidine Tagged Molecules. Bioconjugate Chem. 2009, 20, 1667-1672. 
(24) Nehring, R.; Palivan, C. G.; Casse, O.; Tanner, P.; Tu xen, J.; Meier, W. Amphiphilic Diblock Copolymers for Molecular Recognition: Metal-Nitrilotriacetic Acid Functionalized Vesicles. Langmuir 2008, 25, 1122-1130.

(25) Broyer, R. M.; Grover, G. N.; Maynard, H. D. Emerging Synthetic Approaches for Protein-Polymer Conjugations. Chem. Commun. 2011, 47, 2212-2226.

(26) Bolanos-Garcia, V. M.; Wu, Q.; Ochi, T.; Chirgadze, D. Y.; Sibanda, B. L.; Blundell, T. L. Spatial and Temporal Organization of Multi-Protein Assemblies: Achieving Sensitive Control in Information-Rich Cell-Regulatory Systems. Phil. Trans. R. Soc. A 2012, 370, 3023-3039.

(27) Nussinov, R.; Jang, H. Dynamic Multiprotein Assemblies Shape the Spatial Structure of Cell Signaling. Prog. Biophys. Mol. Biol. 2014, 116, 158-164.

(28) Saka, S. K.; Honigmann, A.; Eggeling, C.; Hell, S. W.; Lang, T.; Rizzoli, S. O. MultiProtein Assemblies Underlie the Mesoscale Organization of the Plasma Membrane. Nat. Commun. 2014, 5. 4059.

(29) Bruns N.; Pustelny K.; Bergeron L.; Whiehead T.; Ckark D. Mechanical Nanosensor Based on FRET Within a Thermosome: Damage-Reporting Polymeric Materials. Angew. Chem., Int. Ed. 2009, 48, 5666-5669.

(30) Griffith, B. R.; Allen, B. L.; Rapraeger, A. C.; Kiessling, L. L. A Polymer Scaffold for Protein Oligomerization. J. Am. Chem. Soc. 2004,126, 1608-1609.

(31) Saluja, A.; Kalonia, D. S. Nature and Consequences of Protein-Protein Interactions in High Protein Concentration Solutions. Int. J. Pharm. 2008, 358, 1-15.

(32) Van Rijn, P. Polymer Directed Protein Assemblies. Polymers 2013, 5, 576-599. 
(33) Cairo, W. C; Gestwicki, E. J; Kanai, M.; Kiessling, L. L. Control of Multivalent Interactions by Binding Epitope Density. J. Am. Chem. Soc. 2002, 124, 1615-1619.

(34) Choe, W.-S.; Clemmitt, R. H.; Chase, H. A.; Middelberg, A. P. J. Comparison of Histidine-Tag Capture Chemistries for Purification Following Chemical Extraction. J. Chromatogr. A 2002, 953, 111-121.

(35) Stadlbauer, S. Coordination Chemistry in Molecular Recognition. Ph.D. Dissertation, University of Regensburg, Regensburg, 2009.

(36) Xia, Y.; Tanga, S.; Olsen, B. D. Site-Specific Conjugation of RAFT Polymers to Proteins via Expressed Protein Ligation. Chem. Commun. 2013, 49, 2566-2568.

(37) Pujar N. S.; Zydney A. L. Electrostatic Effects on Protein Partitioning in Size-Exclusion Chromatography and Membrane Ultrafiltration. J. Chromatogr. A 1998, 796, 229-238.

(38) Arakawa T.; Ejima D.; Li T. S.; Philo J. S. The Critical Role of Mobile Phase Composition in Size Exclusion Chromatography of Protein Pharmaceuticlas. J. Pharm. Sci. 2009, 99, 1674-1692.

(39) Stulik K.; Pacaova V.; Ticha M. Some Potentialities and Drawbacks of Contemporary Size-Exclusion Chromatography. J. Biochem. Bioph. Methods 2003, 56, 1-13.

(40) Lata, S.; Gavutis, M.; Tampé, R.; Piehler, J. Specific and Stable Fluorescence Labeling of Histidine-Tagged Proteins for Dissecting Multi-Protein Complex Formation. J. Am. Chem. Soc. 2006, $128,2365-2372$. 
(41) Liu, T.; Ryan, M.; Dahlquist, F. W.; Griffith, O. H. Determination of pKa Values of the Histidine Side Chains of Phosphatidylinositol-Specific Phospholipase C from Bacillus Cereus by NMR Spectroscopy and Site-Directed Mutagenesis. Protein Sci. 1997, 6, 1937-1944.

(42) Anderson, D. E.; Becktel, W. J.; Dahlquist, F. W. pH-Induced Denaturation of Proteins: a Single Salt Bridge Contributes 3-5 kcal/mol to the Free Energy of Folding of T4 Lysozyme. Biochemistry 1990, 29, 2403-2408.

(43) Turnlund, J. R. Human Whole-Body Copper Metabolism. Am. J. Clin. Nutr. 1998, 67, 960S-964S.

(44) Pereira, M. C.; Pereira, M. L.; Sousa, J. P. Evaluation of Nickel Toxicity on Liver, Spleen, and Kidney of Mice after Administration of High-Dose Metal Ion. J. Biomed. Mater. Res. 1998, 40, 40-47.

(45) Gupta, S. Cell Therapy to Remove Excess Copper in Wilson's Disease. Ann. N. Y. Acad. Sci. 2014, 1315, 70-80.

(46) Guo, H.; Wu, B.; Cui, H.; Peng, X.; Fang, J.; Zuo, Z.; Deng, J.; Wang, X.; Deng, J.; Yin, S. et al. $\mathrm{NiCl}_{2}$-Down-Regulated Antioxidant Enzyme mRNA Expression Causes Oxidative Damage in the Broiler's Kidney. Biol. Trace Elem. Res. 2014, 162, 288-295. 
Table of Contents Graphic

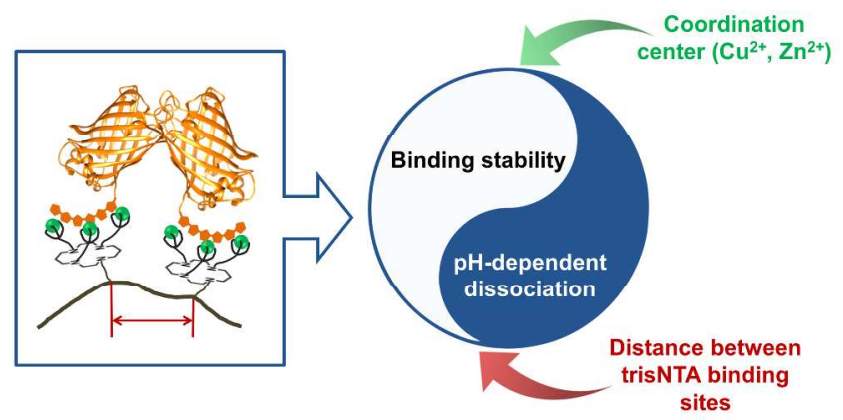

19

20

21

22

23

24

25

26

27

28

29

30

31

32

33

34

35

36

37

38

39

40

41

42

43

44

45

46

47

48

49

50

51

52

53

54

55

56

57

58

59

60

ACS Paragon Plus Environment 
1

2

3

4

5

6

7

8

9

10

11

12

13

14

15

16

17

18

19

20

21

22

23

24

25

26

27

28

29

30

31

32

33

34

35

36

37

38

39

40

41

42

43

44

45

46

47

48

49

50

51

52

53

54

55

56

57

58

59

60
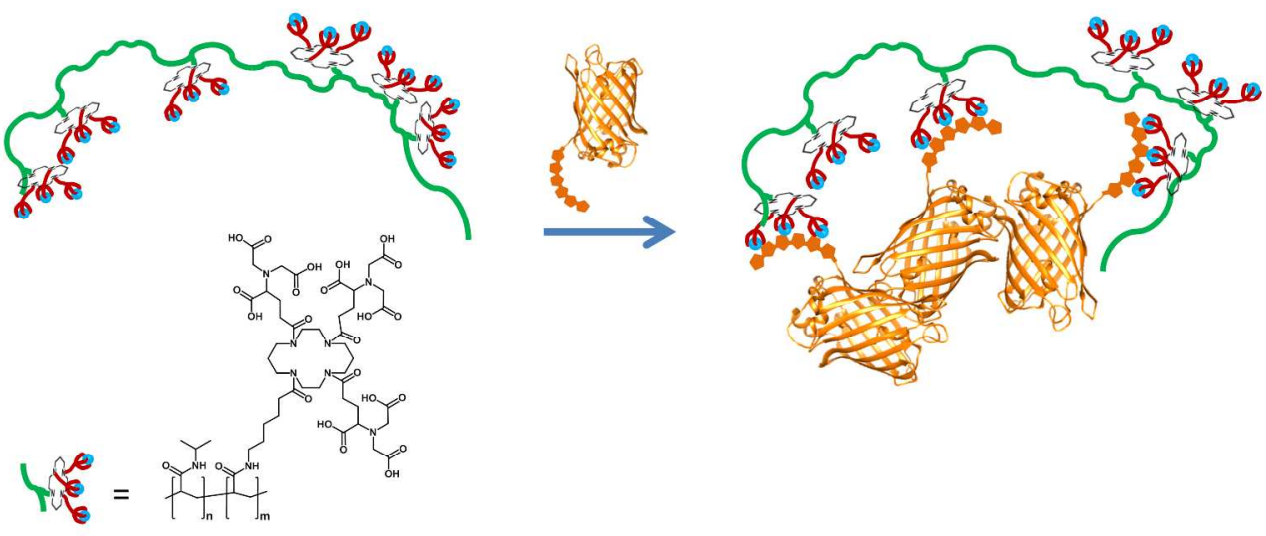

Figure 1. Schematic representation of site-specific conjugation of poly( $\mathrm{N}$-isopropylacrylamide-co-trisnitrilotriacetic acid acrylamide) polymers (green), which coordinate metals (blue) with His-tagged proteins (orange).

$251 \times 114 \mathrm{~mm}(300 \times 300 \mathrm{DPI})$ 


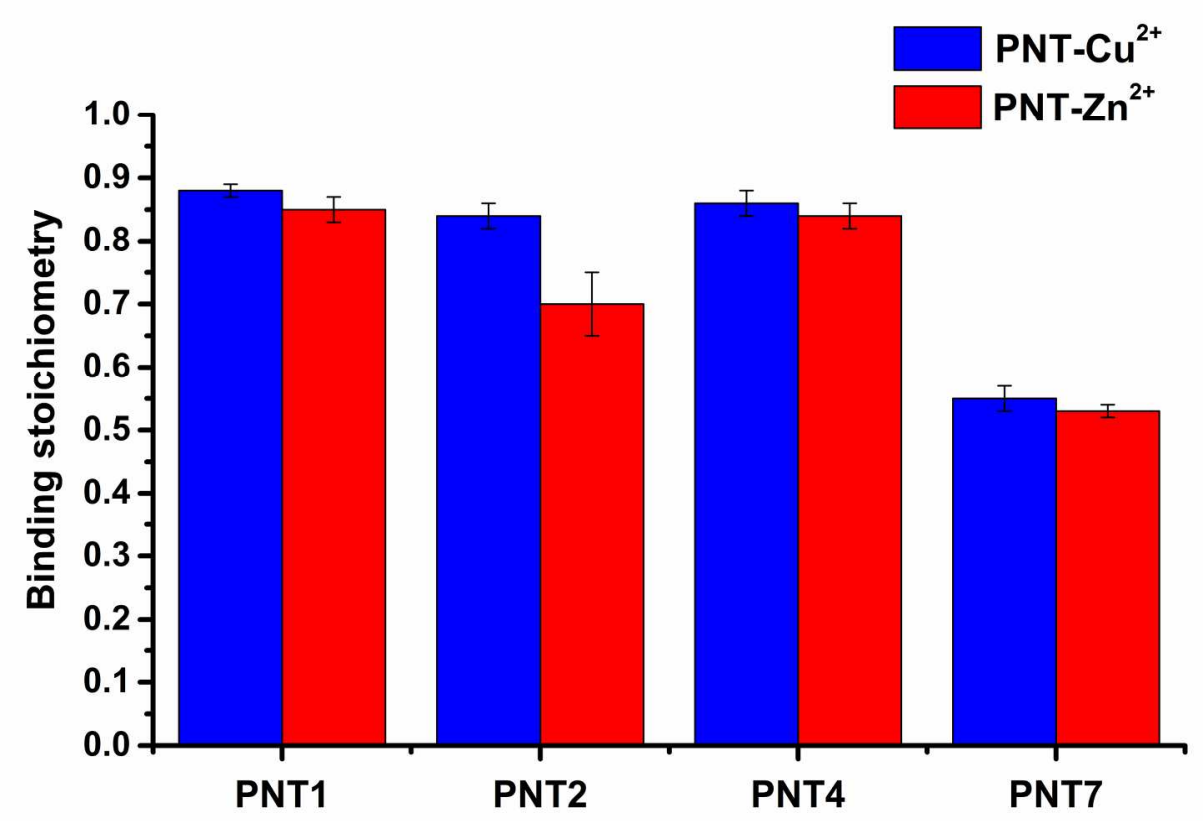

Figure 2. Binding stoichiometry between trisNTA-Me2+ in PNTn and His6-eYFP. $201 \times 140 \mathrm{~mm}(300 \times 300$ DPI) 
Figure 3. KD (M) for the binding between PNTn-Cu2+/Zn2+/Fe3+and His6-eYFP at $\mathrm{pH}=7.4$. $253 \times 87 \mathrm{~mm}(300 \times 300 \mathrm{DPI})$ 
a

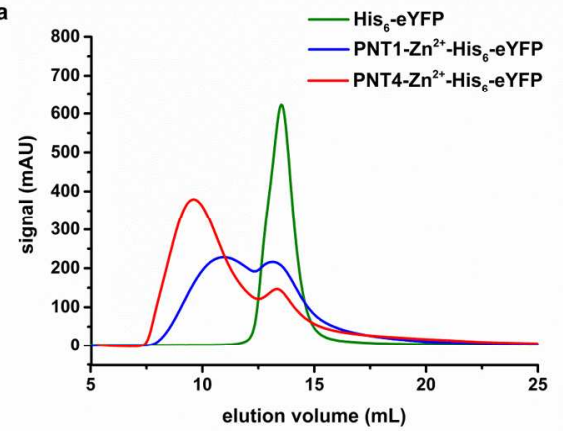

b

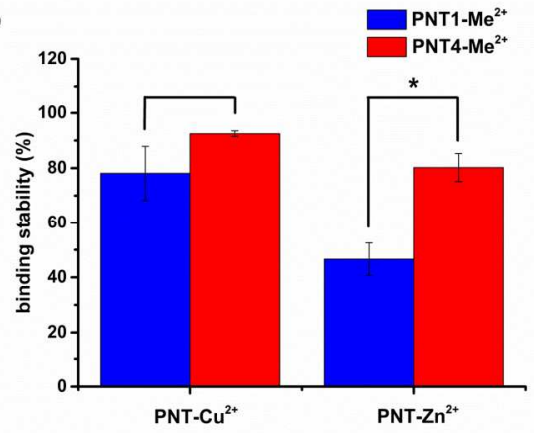

Figure 4. Stability of PNTn-Me2+-His6-eYFP conjugates at pH 7.4. (a) FPLC chromatograms of His6-eYFP and PNT1/4-Zn2+-His6-eYFP. (b) The percentage of His6-eYFP bound with PNT1/4-Me2+. Stars indicate significance in two-tailed Student's t-test; $* \mathrm{P}<0.05, \mathrm{n}=3$.

$238 \times 92 \mathrm{~mm}(300 \times 300$ DPI $)$ 


\section{a}

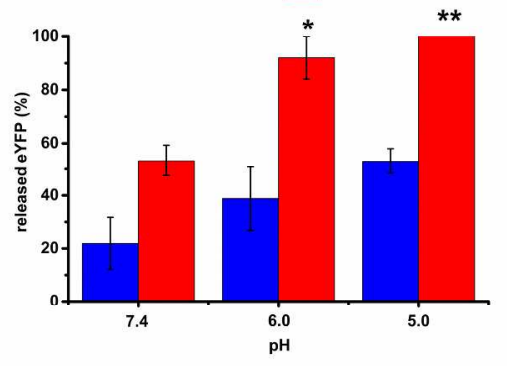

。

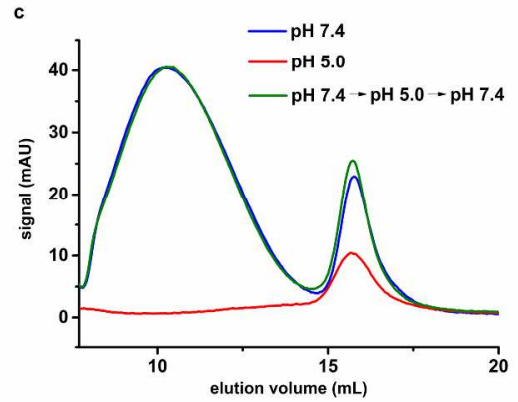

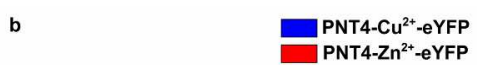

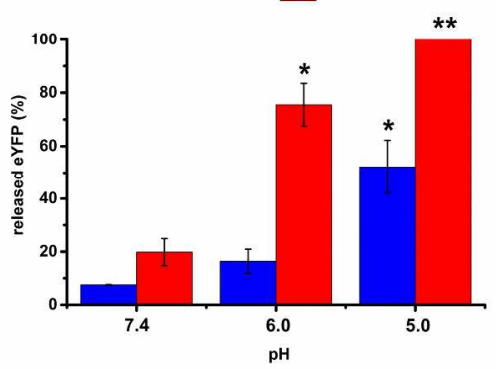

d

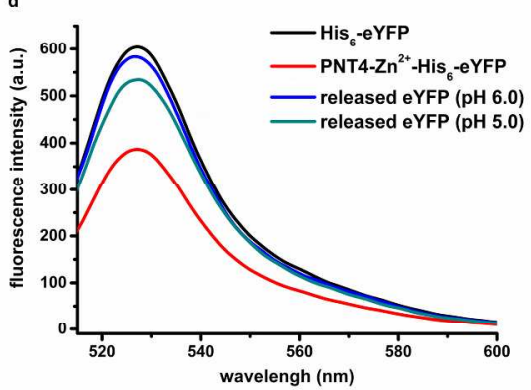

Figure 5. Release of His6-eYFP from PNT1-Me2+ (a) and PNT4-Me2+ (b) at different pH values. All statistics were analyzed by comparing samples to their respective protein-polymer conjugate at $\mathrm{pH} 7.4$. Stars indicate significance compared to the equivalent protein polymer conjugate at $\mathrm{pH} 7.4$ in a two-tailed Student's t-test; $* \mathrm{P}<0.05, * * \mathrm{P}<0.005$. (c) Reversibility of $\mathrm{pH}$ dependent binding between PNT4-Zn2+ and His6-eYFP analyzed by FPLC. (d) The fluorescence emission spectra of His6-eYFP and PNT4-Zn2+-His6-eYFP before and after release in acidic conditions. While reactions were run in acidic conditions, all samples were analyzed at $\mathrm{pH} 7.4$ in PBS.

$254 \times 190 \mathrm{~mm}(300 \times 300 \mathrm{DPI})$ 

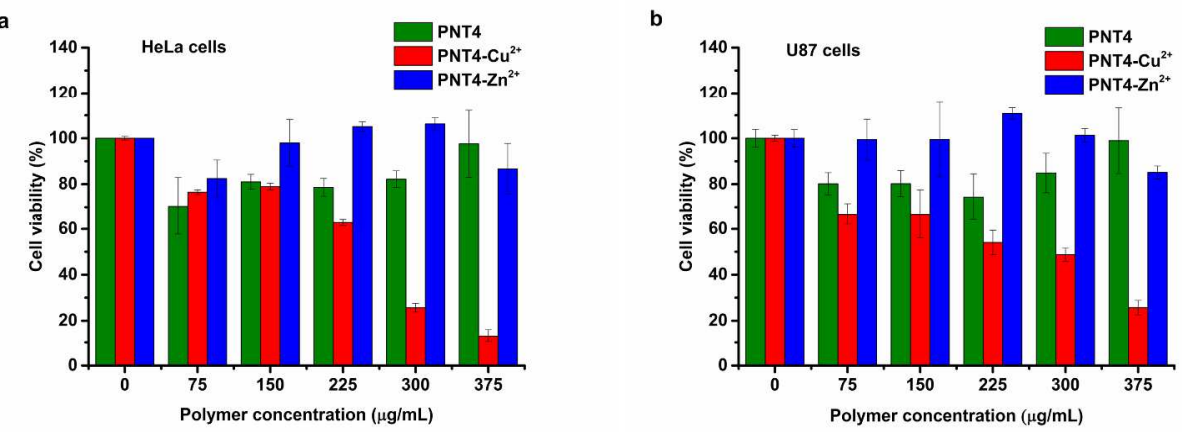

Figure 6. Toxicity evaluation of PNT4-Men+ copolymers on HeLa (a) and U87 (b) cells using MTS assay where zero polymer concentration refers to the addition of PBS to the cells. Errors bars represent the standard deviation $(n=3)$. $244 \times 91 \mathrm{~mm}(300 \times 300 \mathrm{DPI})$ 


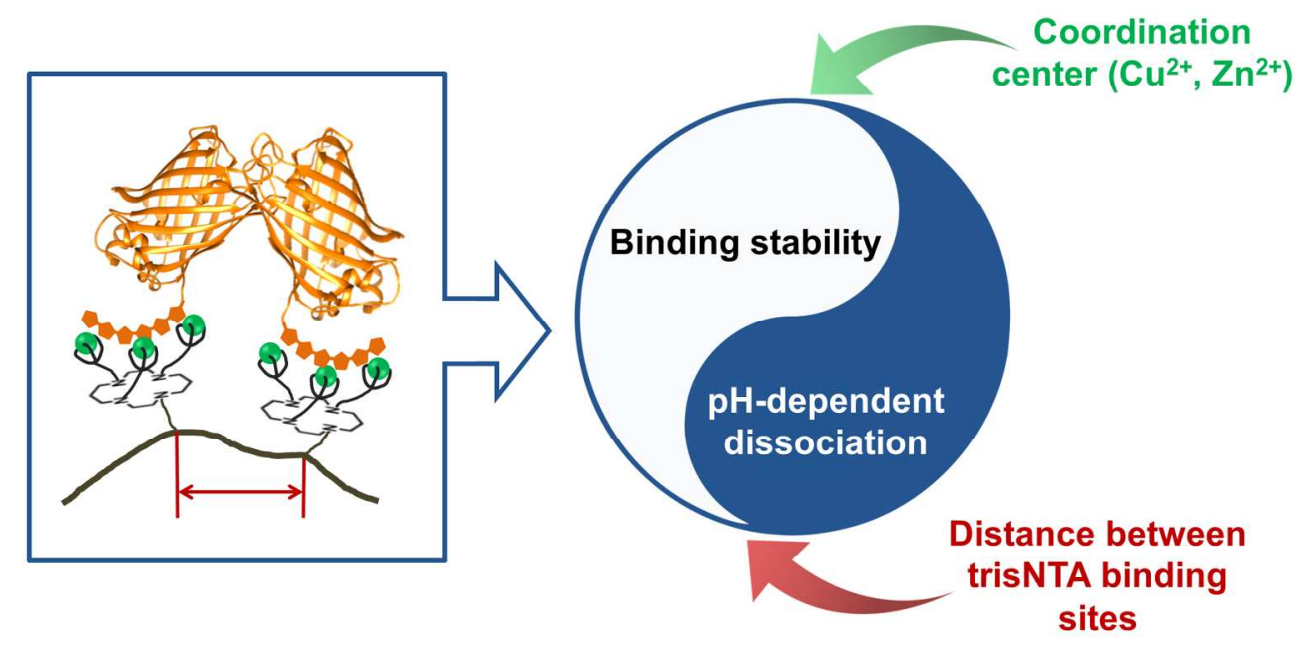

Graphical abstract $325 \times 175 \mathrm{~mm}(150 \times 150 \mathrm{DPI})$ 